\section{Porbjörn Jónsson}

sérfræðingur í ónæmisfræði

og blóðgjafarfræði

formaður Læknafélags Íslands

\title{
Ný ríkisstjórn - ný stefna í heilbrigðismálum?
}

Pann 11. janúar síðastliðinn tók við völdum ný ríkisstjórn, samstjórn Sjálfstæðisflokks, Viðreisnar og Bjartrar framtíðar. Nýr ráðherra heilbrigðismála er Óttar Proppé, pingmaður Bjartrar framtíðar.

Í ársbyrjun 2016 rituðu nærri 87.000 kosningabærir Íslendingar nafn sitt undir áskorunina „Endurreisum heilbrigðiskerfið“ sem Kári Stefánsson læknir gekkst fyrir. Par var pess krafist að 11\% af vergri landsframleiðslu yrði varið til heilbrigðismála, í stað peirra 8,7\% sem nú fara til málaflokksins. Рað er pví ótvíræð krafa almennings til stjórnvalda að auknu fjármagni sé varið til heilbrigðismála á Íslandi.

Í aðdraganda kosninga var nokkur umfjöllun um heilbrigðismál og allir stjórnmálaflokkar voru á einu máli um að efla pyrfti heilbrigðiskerfið, jafnvel stórefla. Rætt var um að: endurreisa pyrfti heilbrigðiskerfið, stytta biðlista, stórauka fjármuni til heilbrigðispjónustu og jafnvel gera hana gjaldfrjálsa, bæta pjónustu við aldraða, framlög til heilbrigðismála yrðu 11\% af vergri landsframleiðslu og lækka pyrfti lyfja- og sjúkrakostnað einstaklinga, svo fátt eitt sé upp talið.

Pess vegna biðu margir í ofvæni eftir stefnuyfirlýsingu nýrrar ríkisstjórnar. ${ }^{1}$ Óhætt er að segja að heilbrigðishluti stefnuyfirlýsingarinnar sé knappur, einungis 176 orð að lengd. Um margt er farið almennum orðum og sum atriði ganga aftur lítt breytt frá stefnuyfirlýsingum fyrri ríkisstjórna. ${ }^{2}$ Ýmsu ber vissulega að fagna. Í stefnuyfirlýsingunni eru fjögur atriði sem ég tel vert að vekja sérstaka athygli á:

- Stefnt skal að pví að minnka greiðslupátttöku einstaklinga í heilbrigðispjónustu.

- Uppbyggingu Landspítalans við Hringbraut verður hraðað eins og kostur er og byggingu meðferðarkjarna lokið árið 2023.

- Aðgengi að geðheilbrigðispjónustu verður aukið.

- Sérstakt átak verður gert til að stytta biðtíma eftir pjónustu í heilbrigðiskerfinu.

Greiðslupátttaka sjúklinga hér á landi hefur árum saman verið meiri en í nágrannalöndum okkar. Á Íslandi hafa sjúklingar purft að greiða um og yfir 18\% af öllum heilbrigðisútgjöldum úr eigin vasa en á flestum Norðurlandanna hefur pessi tala verið nær $15 \%$. Ennfremur má ekki gleyma mikilli umræðu á síðasta kjörtímabili um mál einstakra sjúklinga, einkum sjúklinga með krabbamein, sem lent hafa í hundruða púsunda eða jafnvel milljóna króna útgjöldum í tengslum við veikindi sín. Slík útgjöld ofan á alvarleg veikindi eru mikill baggi fyrir hvert meðalheimili. Рað hefur verið almennur vilji Íslendinga að lagfæra petta og pað starf var hafið á síðasta kjörtímabili.
Unnið hefur verið að undirbúningi nýs Landspítala sleitulaust í hálfan annan áratug og er óhætt að segja að margir séu orðnir langeygir eftir nýjum spítala. Efnahagshrunið 2008 setti páverandi hugmyndir í uppnám en strax árið 2009 var hafist handa við hönnun á nýjum, minni og ódýrari byggingum. Síðan eru liðin 7 ár. Pað er pví gleðiefni að ný ríkisstjórn staðfesti áform fyrri stjórnenda heilbrigðismála um að flutt verði inn í nýjan spítala ekki síðar en árið 2023. Til pess að svo geti orðið purfa framkvæmdir að hefjast skjótt.

Há sjálfsvígstíðni ungmenna á Íslandi hefur verið áhyggjuefni um árabil og umræða um petta vandamál farið vaxandi. Ný ríkisstjórn stefnir að pví að auka aðgengi að geðheilbrigðispjónustu og er sálfræðipjónusta sérstaklega nefnd í pessu samhengi. Ekki parf síður að huga að meiri sérfræðipjónustu geðlækna. Til pess að svo geti orðið parf að laða til starfa íslenska geðlækna sem lokið hafa sérfræðinámi en eru búsettir erlendis. Рað er afar mikilvægt að pessi páttur heilbrigðiskerfisins verði ekki útundan.

Í mörg ár hefur biðtími eftir tilteknum aðgerðum og læknismeðferðum verið of langur á Íslandi. Af og til hefur verið lagt fjármagn í að stytta biðtíma eftir ákveðnum aðgerðum, svo sem augnaðgerðum, bæklunaraðgerðum eða kransæðapræðingum. Pví miður hefur biðtíminn viljað lengjast aftur að átaki loknu. Раð væri sérstakt fagnaðarefni ef ríkisstjórnin gæti unnið skipulega að pví að stytta biðtíma til lengri tíma. Í pessu sambandi má benda á að nýlega opnuðust möguleikar fyrir sjúklinga að sækja læknispjónustu út fyrir landsteinana ef biðtími fer upp fyrir skilgreind viðmið Embættis landlæknis. Slík pjónusta erlendis yrði að mestu leyti greidd af Sjúkratryggingum Íslands.

Í fyrirsögn pessarar ritstjórnargreinar er pví varpað fram hvort ný ríkisstjórn hyggist breyta um kúrs í heilbrigðismálum, móta nýja stefnu í pessum mikilvæga málaflokki. Рað eru vissulega ágætir punktar í stefnuyfirlýsingu nýrrar ríkisstjórnar en pað væri ofmælt að tala um að ný stefna hefði verið mótuð. Pegar pessi orð eru rituð hafa ríkisstjórn og nýr heilbrigðismálaráðherra setið fáa daga að völdum. Рað væri pví ósanngjarnt að mæla eða dæma verk peirra strax. Framundan eru stór mál sem nýr ráðherra parf að kljást við. Læknar eru nú sem fyrr reiðubúnir til að veita stjórnvöldum ráðgjöf um flest pað sem að heilbrigðismálum lýtur.

\section{Heimildir}

1. Stefnuyfirlýsing ríkisstjórnar Sjálfstæðisflokks, Viðreisnar og Bjartrar framtíðar frá 10. janúar 2017: stjornarrad.is/Stefnuyfirlysing/stefnuyfirlysing-rikisstjornar-sjalfstaedisflokksins-vidreisnar-og-bjartrar-framtidar

2. Stefnuyfirlýsing ríkisstjórnar Framsóknarflokks og Sjálfstæðisflokks frá 22. maí 2013: stjornarrad.is/Stefnuyfirlysing/nr/549 